\title{
Memory and the Timeless Time of Eros
}

\author{
Ferdinand Fellmann \\ Department of Philosophy, Chemnitz University of Technology, Chemnitz, Germany \\ Email: ferdinand.fellmann@phil.tu-chemnitz.de
}

How to cite this paper: Fellmann, F. (2017). Memory and the Timeless Time of Eros. Psychology, 8, 963-977. https://doi.org/10.4236/psych.2017.87063

Received: March 28, 2017

Accepted: May 13, 2017

Published: May 16, 2017

Copyright (C) 2017 by author and Scientific Research Publishing Inc. This work is licensed under the Creative Commons Attribution International License (CC BY 4.0).

http://creativecommons.org/licenses/by/4.0/

\begin{abstract}
This paper deals with the perception of time. Chronometric time dominates the rhythm of modern daily life. But in the backstage the inner consciousness of time remains nearly unaltered. Hence, the task of phenomenological psychology is to resolve the paradox of the twofold perception of time. The key to the riddle is remembering. For the modern cognitive approach remembering is considered a construction which is made largely on the basis of chronometric time. I would argue instead that remembering is primarily a matter of feeling or affection. A strong affection is that of love, which overwhelms men and women with great intensity. This experience is analogous in structure and function to involuntary memory which surprisingly brings back lost sensations. When one compares the two famous examples of involuntary memory in the works of Marcel Proust and Henry Miller, the first thing that emerges is something of the nature of Epicurean Eros, the complement of Stoic Logos. According to this idea memory throws light on the timeless time of erotic love as the primary source of personal identity.
\end{abstract}

\section{Keywords}

Personal Identity, Perception of Time, Involuntary Memory, Madeleine Cake, Marcel Proust, Sexual Arousal, Sour Rye Bread, Henry Miller

\section{Introduction}

The dynamics of the partition of time in increasingly digital society changes one's everyday time budget. Most people complain about how time has changed in our culture. They feel pressed for time and are yearning for the good old time of duration. All those who complain about time pressure forget that it is not the technological digitalization itself that makes us feel uncomfortable, but it is the way we deal with it that is problematic. There is a time paradox involved here. Humans have two ways of living: as actors and as feeling subjects. As actors, humans are bound to the clock and play changing roles according to work-life, 
family relations, and leisure balance. As feeling subjects we depend on subjective experiences which constitute our inner self. The complex interplay of the two modes of experience is one main problem in the theory of mind which ordinary psychological discussion tends to ignore.

Ontological theory regards time as an attribute of the punctual Cartesian $\mathrm{Co}$ gito. This position is long outdated in modern phenomenology, which has shown that the stream of consciousness is coherent of time (Husserl, 1928). To understand the temporal succession we need a new method of approach in following our primordial experience of time. This primordial sense of time in its most simple form occurs in sexuality. While the sexual act is going on we have a feeling of timeless flow. This experience can be compared with remembering. Experimental psychology has found out how remembering and temporality are interconnected through specific attitudes (Bartlett, 1995). This has meant a great step forward in the concept of time as actually experienced, but the time paradox of remembering needs further elucidation. If one has been in love, one may recollect things that happened at a fixed date, but the sensation itself cannot be recalled. To overcome the agonizing opposition between objective and subjective time I plead for an intermediate view of time flow-resulting from the natural flow of sexual love. I consider subject and object as two abstract elements of one single function of sexuality called orgasm, in which coition, punctual though it is, is yet (and paradoxically) experienced as duration.

To unravel how time, memory, and erotic arousal are interconnected, I refer to poetic sources that precede and frequently supersede scientific research in richness of understanding in the sense of hermeneutic phenomenology. I first uncover the vital reality of the Madeleine episode in Marcel Proust's In Search of Lost Time. Second, I reconstruct the obscenity involved in the Sour Rye Bread episode in Henry Miller's Tropic of Capricorn. Third, I follow the origins of extra-temporal experience indicative of orgasm and conclude that orgasmic sensations-not to be confused with orgiastic ones-function as unconscious ground for self-consciousness and are unique in the human mind.

\section{Remembered Present in the Madeleine}

Memory is usually considered to be a correlative of the sensible present. I shall turn this relation the other way round and explain how the perception of time is dependent on the memory bank where miraculous sensations come from. The perception of time does not have any intrinsic quality of its own; rather it is associated with a thing or an event that is significant for our emotional life. Most significant for our emotionality is the intimacy of bodily feeling in sexuality. In sexual intercourse chronological time is cancelled, no past, no chance of future, only the here and now of presentational immediacy. This erotic experience is similar in structure to involuntary memory, both of which make emotional life exciting and meaningful (Minkowski, 1933).

Regarding involuntary memory one readily thinks of Marcel Proust's novel In Search of Lost Time. Central to the novel is the famous Madeleine episode in the 
first section of the novel, and in the last volume, Time Regained, in which a flashback similar to that caused by the Madeleine is the beginning of the resolution of the story. Throughout the work many similar instances of involuntary memory, triggered by sensory experiences such as sights, sounds, and smells, conjure up memories for the narrator and sometimes return the reader's attention to an earlier episode of the novel. Whereas many instances of remembering are futile and unimportant, the Madeleine is of an essential meaning for Proust's conception of the human condition.

While Proust was aware of the experience of loss and exclusion-loss of affection, friendship, and innocent joy, which are dramatized in the novel through recurrent jealousy, betrayal, and the death of loved ones-his response to this was that the work of art can recapture and thus save it from destruction, at least in our minds. Art triumphs over the destructive power of time. This element of his artistic thought is clearly inherited from Platonism, but Proust crosses it with a new intensity in evoking a more basic, primordial world, where senses resonate with one another and participate in an intensely emotional state of mind (Jauß, 1986).

The situation is as follows: Due to the usual visit of a family friend, $\mathrm{Mr}$. Swann, the young boy Marcel is deprived of his mother's goodnight kiss, but he gets her to spend the night reading to him. This memory is the only one he has of Combray, until years later the taste of a Madeleine cake dipped in tea inspires a nostalgic incident of involuntary memory. He remembers having had on a Saturday morning a similar snack as a little child with his invalid aunt Leonie, and this leads to more memories of Combray. The Madeleine episode reads as follows:

"No sooner had the warm liquid mixed with the crumbs touched my palate than a shudder ran through me and I stopped, intent upon the extraordinary thing that was happening to me. An exquisite pleasure had invaded my senses, something isolated, detached, with no suggestion of its origin. And at once the vicissitudes of life had become indifferent to me, its disasters innocuous, its brevity illusory-this new sensation having had on me the effect which love has of filling me with a precious essence; or rather this essence was not in me it was me. [...] Whence did it come? What did it mean? How could I seize and apprehend it?... [...] And suddenly the memory revealed itself. The taste was that of the little piece of madeleine which on Sunday mornings at Combray (because on those mornings I did not go out before mass), when I went to say good morning to her in her bedroom, my aunt Léonie used to give me, dipping it first in her own cup of tea or tisane. The sight of the little madeleine had recalled nothing to my mind before I tasted it. And all from my cup of tea." (Proust, Swann's Way, Part 1)

The Madeleine is not just any ordinary cake, it is impressed with the magic of time and the power of the feminine that is contained in its name: Madeleine, 
Mary Magdalena, the sacred prostitute and consort to the Messiah. Because of its scallop-like shape and its soft taste the Madeleine cake is reminiscent of a woman's vulva. The symbolic meaning of the Madeleine cake has been stressed by many interpreters. Despite the exaggerations of some interpreters, the delicate, sophisticated, and courtly manner in which Proust describes the Madeleine experience without doubt refers to sexual experience: “...the shapes-and that of the little shell of pastry, richly sensual under its folds so severe and devout" (Proust, Swann's Way, Part 1). The Madeleine is the expression of the recovery of past time through the symbolic seashell form of the feminine, the primal source that is impressed with the evolutionary architecture of time.

Although Proust wrote contemporaneously with Sigmund Freud, and neither author read the other, there are many points of similarity between their thinking on the structures and mechanisms of the human mind. In a letter of January 3 , 1899, Freud wrote to Fliess: "To the question: 'what happened in earliest childhood?' The answer is 'nothing'. But the germ of a sexual impulse was there" (Freud, 1975: p. 232). Exactly this is the case in the Madeleine episode. Nothing happened while his mother was sleeping in Marcel's room, but the beginning of sexual awareness was there, to be sure.

The sexual awareness of little Marcel in relation to his mother is of a special kind. It is not directed to future adult sexuality, as in Freud's Oedipus, but to the past, namely to the feeling of the maternal womb. The maternal womb is an archetype of the feminine atmosphere Marcel, real namby-pamby that he is, has grown up in. The coming into being for Marcel seems to be ambivalent: the joy of feeling free on the one hand, and the sorrow of being expulsed from paradise on the other. The wonderful figure of the woman-mother to which the boy is bound has formed Proust's conception of erotic love, which is based on the male-female polarity. Into this familiar world, into the sane, touching, loving atmosphere of the household, there intrudes the Baron Charlus, who represents depolarized homosexual love in which doubt and jealousy play diabolical roles. Despite all the sexual bias of the late Proust, the figure of the curative woman, with the mother as the clue, lives on in his intimate relation with Albertine and all her erotic complexity. Proust holds tight to Albertine through a subconscious world of remembered sensations, which give him the sense of moral and ontological security.

What Proust is really playing on in his Madeleine memory is the recovery of the emergence of self-consciousness. To be conscious is to be aware of something external to the mind. Ever since Descartes philosophers have usually connected intentionality with light and intelligence, neglecting its embeddedness in bodily experience and emotionality. In opposition to this the French philosopher Henri Bergson suggests that the immediate data of consciousness, the absolute starting point, as it were, is "duration" (Bergson, 1889). Bergson argued that philosophers traditionally had confused time with its spatial representation. In reality, duration is unextended yet heterogeneous, and so its moments cannot be arranged as a succession of distinct parts, with one part causing the next. Based 
on this, Bergson concluded that freedom is not a breaking up of the chain of cause and effect but the concentration of all past moments in an extraordinary experience of presentational immediacy. In this primordial state the appearance and the content are one and the same. This theory of time and freedom is taken up by Gerald Edelman, who in his work The Remembered Present states that the most striking feature of consciousness is its continuity (Edelman, 1987).

This structure of a streaming present surrounded by a horizon of immediate "retention" of the past and immediate "protention" of the future (both to be distinguished from active thinking) is accessible only in episodes of involuntary memory contained in the Madeleine cake. The Madeleine experience cancels any implication of chronology. In memory Proust finds two modes of experience: perception and desire, which correspond to Bergson's Matter and Memory (1896). Mediating between both modes is the aesthetic attitude, and this is the essential meaning of involuntary memory. The Madeleine cake is the window into Proust's own self where he finds the mediation. His remembered pre-reflected self is like the monad of Leibniz which has no windows. The monad represents the fully concrete ego with its constituted as well as its constituting components, its actualities, its potentialities experienced in the primal contact with the female body.

At the end of the volume Time Regained, the narrator discerns the meaning of his involuntary memory: by putting him in contact with both the past and present, the impressions allow him to gain a vantage point outside real time, affording a glimpse of the true nature of time, which he calls the $4^{\text {th }}$ dimension of space, while entering into an aisle in a church. He realizes that his whole life has prepared him for the mission of describing events as fully revealed, and finally he is spurred to writing. He is afraid of dying through an external incident or a cerebral stroke. But he realizes that his novel carries within itself the accumulated baggage of his past, and he concludes that everyone occupies an immense range "in Time" which is indestructible and a sign of eternity. The memory of love above all helps persons to overcome the fear of death. This focus on the relationship between experience, memory, and consciousness, as well as the radical neglect of the outside world, makes Time a substitute of God the Almighty.

\section{Henry Miller and the Taste of Rye Bread}

Whereas Proust in his search of "absolute reality" is bound to metaphysical essentialism, Henry Miller leaves essentialism behind. In Tropic of Capricorn, his best work, consciousness is characterized by a certain sort of spontaneity and corresponds to Sartre's formula that existence precedes essence. In this Miller is on the road towards modern existentialism: "We are dancing in the hollow of the cup of nothingness" (Miller, 1961: p. 121). In another text, The Cosmological Eye, Miller exclaims: “The present? There's no such thing as the present. There's a word called Time, but nobody is able to define it. There's a past and there's a future, and time runs through it like an electric current. The present is an imaginary condition, a dream state... an oxymoron" (Miller, 1961a: p. 141). The 
core of this ambivalent feeling is the maternal womb, the origin of lived time: "I see around myself as the role of the mother who bore me once saw round the corners of time" (Miller, 1961: p. 122).

Unlike Proust, Miller as a boy grew up on the streets of Brooklyn where he acquired a sort of gangster mentality. As the Madeleine cake is the window into Proust's self, so is the sour rye bread the window into Miller's rootless self. The rye bread episode runs as follows:

"My cousin Gene and I had been corralled by a gang of boys while we were playing in the park. We didn't know which side we were fighting for but we were fighting in dead earnest amidst the rock pile by the river bank. We had to show even more courage than the other boys because we were suspected of being sissies. That's how it happened that we killed one of the rival gang. Just as they were charging us my cousin Gene let go at the ring leader and caught him in the guts with a handsome-sized rock. I let go almost at the same instant and my rock caught him in the temple and when he went down he lay there for good and not a peep out of him. A few minutes later the cops came and the boy was found dead. He was eight or nine years old, about the same age as us. What they would have done to us I don't know. Anyway, as not to arouse any suspicion we hurried home; we had cleaned up a bit on the way and had combed our hair. We walked in looking almost as immaculate as when we had left the house. Aunt Caroline gave us our usual two big slices of sour rye with fresh butter and a little sugar over it and we sat there at the kitchen table listening to her with an angelic smile" (Miller, 1961: p. 124).

Different from Proust's Madeleine, Miller's sour rye bread has no symbolic form that is reminiscent of the female vagina. The rye bread stands for a murderous incident and the experience of early guilt. And Aunt Caroline-the equivalent of Proust's aunt Leonie-stands for maternal care and offers tacit absolution: "I think if I had told my Aunt Caroline that I had killed a boy in the lot, told her just how it happened, she would have put her arms around me and forgiven me-instantly" (Miller, 1961: p. 127). For her, being is morally more important than doing.

The relation of the incident to sex occurs in the Weesie episode. Weesie is a little girl down in the cellar who is paid to lift up her dress by the urchins. Henry was immediately in love with Weesie, and she was the first person of the other sex who admired Henry for being different. His first sexual awareness in looking underneath the dress of the young girl is directed into the future of adult sexuality. Weesie is the prefiguration, the "figura" of Miller's great love: Mona. As a professional dancer Mona is paid by the customers and, at the end of the story, she tells Miller that she had a horrible experience with a man (her father?) who took her home and suddenly pulled up her dress (Miller, 1961: p. 344).

Miller is a city man, a man of New York, which for him represents the natural environment. New York is embodied in Mona, the pretty woman he had met in 
a dance hall. Miller describes her coming: "What a walk! It's not a walk, it's a glide. Tall, stately, full-bodied, self-possessed, she cuts the smoke and jazz and red-light glow like the queen mother of all Babylonian whores. [...] Broadway-it's her realm. This is Broadway, this is New York, this is America. She is America on foot, winged and sexed" (Miller, 1961: p. 342). The way that Mona moves across the street nears Miller's primary definition of eroticism. At the beginning of his story Miller knew Mona had something special—but what exactly, he is unsure. But now, at the end, he realizes with much more provocative clarity: the way a woman moves is an interpretation of his sexual desire, as well as her sexuality, in general: "No past, no future. Even the present seems dubious... No beginning, no end, I'm aware not of time nor the passing of time, but of timelessness" (Miller, 1961: p. 346).

The attachment to his mother has shaped Proust's intimate relations to women, especially to Albertine. He is attracted to her and is yearning for her presence, but in possessing her he still is not content. In Miller's life, on the contrary, the mother does not play an emotionally impressive role. His relation to women is casual and sexoriented; he considers them mere objects of lust. His sexual display has been regarded as pornographic, but this is not the case. Miller himself rejects pornography, pleading for obscenity instead. Obscenity is difficult to define. In obscenity time is concentrated in little pauses of pleasure and desire, a state of integral feeling induced by the Madeleine cake. Miller considers the obscene acts he describes a way of self-preservation; every act of sexual intercourse corresponds to the murderous act of the young boy. The rye bread may stand for forgiveness, but it does not cancel out the aggression. Whereas the Madeleine is a symbol of harmony, the rye bread stands for pre-stabilized disharmony, experienced as "good destruction," the only form of construction possible for humans in love.

Miller's complex experience of aggressive sexuality is symbolized in Mona, the only woman he really loves. Mona is more significant and much more erotically charged than the simple-minded Albertine of Proust. Miller is enslaved by Mona's insatiable sexual desire, but at the same time she represents the female myth, the mythical creature Helena. All the girls and women that Miller ever possessed are incorporated in Mona. She is for him mother and lover in one person, a goddess as well as a whore. One could call her the "Eternal Feminine" that draws man down as well as lifts him up.

By projecting his experience of repeated sexual acts onto Mona, Miller obviously follows the ideas of the psychotherapist Otto Rank, whom he consulted in Paris. Rank, as opposed to Freud, made emotional relationships central to his practice of psychotherapy. For Freud, the Oedipuscomplex was the foundational source of all art, myth, religion, philosophy, therapy-indeed of all human culture and civilization. In 1924, Rank published Das Trauma der Geburt (The Trauma of Birth, 1929), exploring how art, myth, religion, philosophy, and therapy were illuminated by separation anxiety in the "phase before the development of the Oedipus complex" (p. 216). To overcome separation anxiety Mil- 
ler, following Rank, is in search of a second birth into a world of his own: "Every one, whether consciously or unconsciously, is trying to recover the luxurious, effortless sense of security which he knew in the womb. Those who are able to realize themselves do actually achieve this state; not by a blind, unconscious yearning for the uterine condition, but by transforming the world in which they live into a veritable womb" (Miller, 1961a: p. 280). This veritable womb is found by Miller in long, drawn out, and agonizing orgasms.

Miller's search for his own orgasmic self can be compared with that of the American writer Anais Nin. Like Miller, Nin consulted Rank and recounts the transformation she underwent in her therapy with Rank. Rank, she observes, helped her move back and forth between what she could verbalize in her journals and what remained unarticulated. She discovered the quality and depth of her feelings in the wordless transitions between what she could say and what she could not say. "As he talked, I thought of my difficulties with writing, my struggles to articulate feelings not easily expressed. Of my struggles to find a language for intuition, feeling, instincts which are, in themselves, elusive, subtle, and wordless" (Nin, 1966: p. 276).

Miller met Nin in 1931 and was fascinated by her diaries, which he compared with those of Marcel Proust. In his portrait of Anais Nin, "Un etreétoilique" (1934 in: The Cosmological Eye), he writes: "It is the first female writing I have ever seen: it rearranges the world in terms of female honesty..." (Miller, 1961a: p. 289). Although she is female, in Nin's world of erotic love both male and female are present: "The tension is perfect, the polarity absolute. The voices of the earth mingle with an eternal resonance which issues from the delta of the feconding rivers of death [...]. Nothing lost, nothing used up, nothing relinquished. The great mystery of conservation in which creation and destruction are but the antipodal symbols of a single constant energy which is inscrutable" (Miller, 1961a: p. 290).

Miller struggles desperately for authorship. In search of his own self, he declares: "For there is only one great adventure and that is inward toward the self, and for that, time nor space nor even deeds matter" (Miller, 1961: p. 12). Miller has an enduring dream of passing the boundary line (Miller, 1961: p. 218). And he is fascinated by the experience of being reborn: "The man who is reborn, ... The man whom God loves is the onion with a million skins" (Miller, 1961: p. 230). This can be read as a translation of Rank's theory of individual development. In a 1938 lecture, Rank said:

"Life in itself is a mere succession of separations. Beginning with birth, going through several weaning periods, the development of the individual personality, and finally culminating in death-which represents the final separation. At birth, the individual experiences the first shock of separation, which throughout his life he strives to overcome. In the process of adaptation, man persistently separates from his old self, or at least from those segments of his old self that are now outlived. Like a child who has outgrown a toy, he discards the old parts of himself for which he has no further use... The ego continually breaks away from its 
worn-out parts, which were of value in the past but have no value in the present. The neurotic [who cannot unlearn, and, therefore, lacks creativity] is unable to accomplish this normal detachment process... Owing to fear and guilt generated in the assertion of his own autonomy, he is unable to free himself, and instead remains suspended upon some primitive level of his evolution" (Rank, 1996: p. 270).

Miller compares sexual experience to religious experience. God who is defined as actus purus by medieval theologians has lost his significance: "If I had the chance to be God I would reject it. If I had the chance to be a star I would reject it. The most wonderful opportunity which life offers is to be human. It embraces the whole universe. It includes the knowledge of death, which not even God enjoys" (Miller, 1961: p. 229). Eros and Thanatos are bound together in a human's time of life and make life time human. "Time passes, but it is not clock time; nor is it poetic time such as men create in their passion. It is more like that aonic time required for the creation of gems and precious metals; an emboweled sidereal time in which the female knows that she is superior to the male and will eventually swallow him up again. The effect is that of starlight carried over into day-time" (Miller, 1961a: p. 289).

Employing repeated sex as a literary technique of spiral form, accumulating a legion of amorphous images, Miller delves into an illusory realm of timelessness where his self does all his thinking via orgasm. With such a-temporal moments of sexual intercourse Miller tries to overcome the secular time of time clocks. To step outside of chronological time was a promise, but at the end Miller realized the ultimate futility of such a course. Sexual abandon alone cannot constitute a goal in and of itself, and it cannot remove him from the cosmodemonic purgatory in which he exists as a writer. Progression toward artistic consciousness requires more: "We must get going. Tomorrow, tomorrow...".

\section{Eros and the Timeless Time of Mental Orgasms}

Following Proust and Miller I have tried to describe and to explain the uniqueness of human self-consciousness in the light of erotic experience. Unfortunately, eroticism is often equated with crude sexuality. But actually, eroticism is close to sexuality and at the same time transforms it into a spiritual issue fundamental for true love (Fellmann, 2016). The same can be said of orgasm, the climax of sexual intercourse. For lovers orgasmic sensations are usually not restricted to the genitals; they invade the whole body and mind. I am therefore pleading for a structural or formal analogy between erotic arousal and the self-feeling of an individual. Both show a curious ambiguity in the experience of time that corresponds to profound sex differences in psyche according to the male-female polarity.

To clarify this idea it is helpful to refer to descriptions of orgasm. D. H. Lawrence in his novel Lady Chatterley's Lover gives an explicit account of the sexual act: "Sharp soft waves of unspeakable pleasure washed over her as he entered her, and started the curious molten thrilling that spread and spread till she was 
carried away with the last, blind flush of extremity" (Lawrence, 1961: p. 220). A vast amount of literature exists about the evolution of female orgasm. Fundamentally different theories have been proposed to account for the male-female differences. As far as I know, none of these theories connects orgasmic sensations with the experience of time. Orgasm in humans is the climax of intense sexual arousal. Physiologically it is the synchronic motion of two bodies and convulsive contractions in the contact of the genitals; psychologically it is a race to the desired end, which, when reached, flows down: post coitum omne animal triste. This process involves different modes of time: the rushing time of increasing lust, the time-destroying actus purus of the apex, and the slow flow of feeling good afterwards. In orgasm this experience is carried over into the realm of consciousness; it comes not as a shock or novelty but as the very vehicle of déjà $v u$, a pulsation which springs from the cosmic life-rhythm: "Motionless, and in the invisible flame of another consciousness, he sat with his hand on her, and waited for the turn" (Lawrence, 1961: p. 221). Thus, the inner consciousness of time is the medium which unites body and mind. What is expressed in orgasm is the extremely intense experience of a man and a woman coming together. In this, orgasmic "high noon" is analogous to involuntary memory as the primal sense of life-impulse out of which emerges an overpowering act of creation that is far more than procreative. This is what I mean when I speak of "mental orgasms" as the rhythm of the mind that represents the dialectic of male and female, who are socially equals, though mentally different.

The complex temporal structure of erotic love shows that objective clock time is based on male sexual desire whereas lived time corresponds to female receptiveness which integrates activity and passivity. One may speak of the polarity of time as the primary tie between man and woman in unrepenting sensuality. The two modes of time are not mere opposites; they interact and come together at a higher level of communication and integration called the "mating mind." This can be shown in organic life. Biological time is the interference of clock time and remembered time. Augustine presents us with the paradoxes which arise when one considers that past and future existences do not, properly speaking, exist, but that the present is an infinitesimally small instant of existence. The present is not only the boundary between past and future but an agent that holds together past and future. This is the essence of life which is not in time but which creates time (von Weizsäcker, 1942).

Time Flow, Temporal Passage-the picture of time as passing or flowing is extremely common. Yet for analytical philosophers temporal passage has nothing to do with the real world, but with subjective consciousness. In 1895 H. G. Wells published The Time Machine, a science fiction novel in which he popularized the concept of time travel by using a vehicle that allows an operator to travel purposely and selectively forwards or backwards in time. The idea of traveling through time derives from the theory that time is simply a fourth dimension of the environment of life. This concept of the world laid out in four-dimensional space-time has been worked out by the mathematician Hermann Min- 
kowski. By 1907 Minkowski realized that the special theory of relativity, as introduced in 1905 by his former student Albert Einstein, could best be understood in four-dimensional space, since known as the "Minkowski spacetime," in which time and space are not separate entities but fused in a four-dimensional space-time: "Henceforth space by itself, and time by itself, are doomed to fade away into mere shadows, and only a kind of union of the two will preserve an independent reality." (Minkowski, 1909) But careful reflection on the kind of union of space and time shows that Minkoswki's explanation in terms of causal efficiency falls short. His mathematical formula does not give an idea of the intersection of causal efficiency and presentational immediacy. This intersection is lived in love as a specifically human kind of bodily communication. It is mandatory therefore to construct a model of human life-world in which time flow and love flow coincide, like water willy-nilly flowing.

Time is not part of the objective world but can be found only as dimensions of our terrestrial being: present, past, and future. Through body image with its libidinal structure the mind is not merely in objective time, but introduces into the present the phenomenon of past and future. The Madeleine causes Proust to travel into the past, the rye bread has Miller going into the future. This ecstatic outreaching of temporality leads not only to think of reasons to live but also of the season to love:

Just let your love flow like a mountain stream

And let your love grow with the smallest of dreams

And let your love show and you'll know what I mean

It's the season

The popular song of the Bellamy Brothers demonstrates how the season of love opens up a reason to participate in the life of another person. The experience of the unity of two lovers seems to be unique in the animal kingdom. This takes us back to the mysteries of hominization. Different from animals that are one with their environment, human consciousness is always full of contradictions, of disharmony that makes adaption so difficult.

Evolutionary biologists have reconstructed the process of hominization along the lines of behavior, strategic learning, and cognition. However universal cognition may be, I believe that emotion is still more basic, and that it is emotion that has taught humans to reason. Natural selection is overlaid by sexual selection that corresponds to "emotional selection" (Fellmann \& Walsh, 2013). Sexual emotion is the source of our most intense pleasure, and thus making love has to become a reward in itself. For this unusual and irritating view-most of us still think that sexuality is merely brutish-one can find support in poets, who in their picture of the human mind are not restricted to cognitive analysis. To begin with emotionality would help us to get a better understanding of the unique nature of human self-consciousness with its built-in conflicts between the sexes.

Musing about the woman, Miller writes: "Looking into the backs of her eyes, into the pulpy translucent flesh, I saw the brain structure of all formations, all 
relations, all evanescence, I saw the brain within the brain..." (Miller, 1961: p. 232). What Miller expresses as a poetical vision has been confirmed empirically by modern neuroscientists. Whereas Bergson stated that memory, as opposed to perception, is absolutely independent of matter and can never be deduced from a brain process, neurobiological research has shown the contrary. A long series of distinctions have made the concept of memory extremely complex. To name only the most important distinctions of the causal theory of propositional memory: primary versus secondary memory, short-term memory versus long-term memory, working memory, multiple attentional systems, different levels of processing, and so on (Bernecker, 2012). The influences of emotion on memory have been broadly studied recently (Kensinger \& Schacter, 2014). Essential for our context of emotional memory is the difference between episodical and semantic memory (in French: souvenir-mémoire, in German: Erinnern-Gedächtnis). Semantic memory refers to meanings which are timeless. Episodic memory refers to personal experiences in a definite place at a definite time. For instance, one remembers the occasion when one had to memorize a poem, but one does not remember which poem it was. On the other hand, episodic memories are not always in chronological sequence. Usually the revival is not in one recalled picture but in superimposed pictures. So, the taste of the Madeleine shows Proust sights of Combray he was not aware of before. And Miller in his agonizing orgasms is aware of the rich bodily constitution of Mona, the only woman he really loved.

The complex structure of memory is like that of erotic arousal with its tendency to creative evolution. Erotic arousal refers not only to the present, but paradoxically creates fictitious references and brings forth wished-for situations. The phenomenon of fulguration, the creative flash transcends reality. In appearance the remarkable thing is the vividness of the impression and the firm conviction to remember things never experienced. Consequently, "duration" is not empty, not a blank, but full of the timeless time of the mind in creation where imaginary memories come from. These original experiences can be considered as deep phenomenological insights into the realm of the unconscious.

As to the evolutionary basis of memory I argue that the impact of erotic emotionality deriving from the overflowing energy of sexual impulses was essential for the large size of our brains (Fellmann/Walsh, 2016). Millions of years of the upright gait and tool-making did not change the size of the brain. Only the emotional side of pair-bonding through mutual mate choice, namely the stress of complete intimacy, is responsible for the fabric of the human brain. This is confirmed by Geoffrey Miller, who wrote about the "runaway brain," and by Helen Fisher, who talked of "scanning the brain in love" (Fisher, 2004; Miller, 2001).

In regard to time, erotic love of humans expresses a gap between body and soul, between life-time and cosmic time. In orgasm the peculiarity of the situation and the intensity of the attendant feeling transform human self-consciousness into an internal flow until the end of time. To put it poetically: "Pereunt et imputantur" - the hours perish and are laid to account: "Almost all pathos in- 
cludes a reference to the lapse of time. The final stanza of Keats' Eve of St. Agnes commences with the haunting lines:

And they are gone: ay, ages long ago

Those lovers fled away into the storm.

There the pathos of the lapse of time arises from the imagined fusion of the two perceptive modes by one intensity of emotion" (Whitehead, 1985: p. 47).

The clash of these two different perceptive modes is the royal road to redeem the flows and rhythms as we interact with one another. And orgasm, in French literature called the "little death," is the fore-taste of the real death. Shelley, in his poem The Boat on the Serchio, associates orgasm with death when he writes "the death which lovers love." Shakespeare was aware of this idea: the lines "I will live in thy heart, die in thy lap, and be buried in thy eyes," and "I will die bravely, like a smug bridegroom"-respectively Benedick in Much Ado About Nothing and King Lear in the play of that ilk-are interpreted to mean "to experience a sexual orgasm." Sigmund Freud in The Ego and the Id (1923) speculates that sexual satisfaction by orgasm leave Eros ("life instinct") exhausted and opens up the field to Thanatos ("death instinct"); in other words, in orgasm Eros fulfills its mission and gives way to Thanatos.

I do not share Sigmund Freud's pessimism, which was in part due to the political thread of the 1920s. The feeling of life and death and mortality and immortality which we acquire in our journey through the wilderness of our world is often frightening and sad, but very fine. To be sure, Thanatos is always planning his dreadful revenge against the world of Eros, where he will never be at home. But this is the future that we are not able to foresee. Reality is here, in a single moment of time, in the exciting feeling of erotic love. Eroticism is a continual attempt to refine answers to the question of what makes us human. The answers can be applied to Eros, the great artist, whose memory stays with us even after the candle has gone out (Kubler, 1962). Here the past and the present fuse, and life, with its trivial devices and desires, seems only a moment in eternity. The orgasmic redemption of our own time-passing the boundary line between life and death-generates the notion of the sublime unknown to animals. This is our fate as well as our chance.

\section{Conclusion}

To conclude, after this poetic excursion, I will return to the sober style of rigorous science. But I want to remind psychologists that poems, songs, and even kitsch often reveal more about the human mind than scientific research. Scientific knowledge may be truth, but it is not evidence. Committed to intuitive evidence my question is no longer what a human being is, but what it is like to feel as a human being. The answer is: to feel human is to be aware of the inner consciousness of time. Cultural variable concepts of time are found in ritual practices only, whereas in emotional communication humans have an invariant, universal experience of lived time. From this there follow three aspects of anthro- 
pology:

Psychological: Regarding the perception of time, Augustine has left us with the paradoxes that arise when one considers that past and future do not, properly speaking, exist, and that the present is a vanishingly small instant of existing. But when we change our perspective from chronometric time to lived time, consciousness becomes an absolute stream of thought, a feeling of existence not subject to the difference between appearance and reality. This timeless selfexpression and self-validation is the source of our personal identity.

Biological: Sexual desire strikes men and women like lightning. Paradoxically, the momentary flash in orgasmic arousal is experienced as timeless. In ancient myth the timeless time of orgasm is represented by the God Eros, the spiritual side of human sexuality. From the evolutionary point of view Eros points back to the unconscious origin of human life. In that respect, human's complex living together harmoniously and inharmoniously differs from animal mating behavior. The difference corresponds to the difference between sexuality as a means of procreation and eroticism as a mental activity and pleasure in itself.

Sociological: Eroticism may cause disorder in society. On the other hand, erotic emotions are higher-order emotions which have brought humans to practice romantic fiction. In romantic fiction sexuality is upgraded to a higher level of emotional participation. To participate in life is like erotic love where past and present sensations are fused and thus transformed into the feeling of freedom from social constraints. Participation and empathy is the royal road to the discovery of the self in relation to someone else-a feeling of mutual understanding which constitutes our view of the life-world ("Lebenswelt"), unique to the human mind.

\section{Acknowledgements}

The author would like to thank Rebecca Walsh and Horst Kruse for the suggestions made in the revision of this paper.

\section{References}

Bartlett, F. C. (1995). Remembering. A Study in Experimental and Social Psychology. Cambridge: University Press. https://doi.org/10.1017/CBO9780511759185

Bergson, H. (1889). Essai sur les donnéesimmédiates de la conscience. Paris: Alcan.

Bergson, H. (1896). Matière et mémoire. Paris: Alcan.

Bernecker, S. (2012). Memory: A Philosophical Study. New York, NY: Oxford University Press.

Edelman, G. (1987). The Remembered Present: A Biological Theory of Consciousness. New York, NY: Basic Books.

Fellmann, F. (2016). Eroticism: Why It Still Matters. Psychology, 7, 976-983. https://doi.org/10.4236/psych.2016.77098

Fellmann, F., \& Walsh, R. (2013). Emotional Selection and Human Personality. Biological Theory, 8, 64-73. https://doi.org/10.1007/s13752-013-0093-3

Fellmann, F., \& Walsh, R. (2016). From Sexuality to Eroticism: The Making of the Hu- 
man Mind. Advances in Anthropology, 6, 11-24.

https://doi.org/10.4236/aa.2016.61002

Fisher, H. (2004). Why We Love: The Nature and Chemistry of Romantic Love. New York, NY: St. Martin's Griffin.

Freud, S. (1975). Briefe an Wilhelm Fließ. Frankfurt am Main: S. Fischer.

Husserl, E. (1928). Vorlesungen zur Phänomenologie des inneren Zeitbewusstseins. Halle (Saale): Niemeyer.

Jauß, H. R. (1986). Zeit und Erinnerung in Marcel Prousts A la recherche du temps perdu. Frankfurt am Main: Suhrkamp.

Kensinger, E. A., \& Schacter, D. L. (2014). Memory and Emotion. In M. Lewis, J. Haviland-Jones, \& L. Feldman Barrett (Eds.), Handbook of Emotion (3rd ed., pp. 601-617). New York, NY: Guilford Press.

Kubler, G. (1962). The Shape of Time. Yale, CT: University Press.

Lawrence, D. H. (1961). Lady Chatterley's Lover. London: Penguin Books.

Miller, G. (2001). The Mating Mind. How Sexual Choice Shaped the Evolution of Human Nature. London: Vintage

Miller, H. (1961). Tropic of Capricorn. New York, NY: Grove Press.

Miller, H. (1961a). The Cosmological Eye. New York, NY: New Directions.

Minkowski, E. (1933). Le Temps vécu, études phénoménologiques et psychopathologiques. Paris: Payot.

Minkowski, H. (1909). Raum und Zeit. 80. Versammlung Deutscher Naturforscher (Köln, 1908). In Physikalische Zeitschrift. 10 (pp. 104-111).

Nin, A. (1966). The Diary of Anaïs Nin: 1931-1934 (Volume 1). New York: Houghton Mifflin Harcourt.

Proust, M. (1913-1927 engl. 1922-1931). In Search of Lost Time. Swann's Way Part 1, Time Regained.

Rank, O. (1996). The Trauma of Birth. New York, NY: Dover Publications.

von Weizsäcker, V. (1942). Gestalt und Zeit. Halle (Saale): Max Niemeyer.

Whitehead, A. N. (1985). Symbolism. Its Meaning and Effect. New York, NY: Fordham University Press.

Submit or recommend next manuscript to SCIRP and we will provide best service for you:

Accepting pre-submission inquiries through Email, Facebook, LinkedIn, Twitter, etc. A wide selection of journals (inclusive of 9 subjects, more than 200 journals)

Providing 24-hour high-quality service

User-friendly online submission system

Fair and swift peer-review system

Efficient typesetting and proofreading procedure

Display of the result of downloads and visits, as well as the number of cited articles

Maximum dissemination of your research work

Submit your manuscript at: http://papersubmission.scirp.org/

Or contact psych@scirp.org 